Saudi Journal of Humanities and Social Sciences

Abbreviated Key Title: Saudi J Humanities Soc Sci

ISSN 2415-6256 (Print) | ISSN 2415-6248 (Online)

Scholars Middle East Publishers, Dubai, United Arab Emirates

Journal homepage: https://saudijournals.com

Original Research Article

\title{
Innovation Program of Indonesia Movement Aware of Population Administration
}

\author{
Muhammad Aldhietya Aswatra ${ }^{1}$, Budi Suryadi ${ }^{2 *}$, Siswanto $^{3}$ \\ ${ }^{1}$ Master of Government Science Students, Lambung Mangkurat University, Indonesia \\ ${ }^{2,3}$ Faculty of Social Science and Political Science, Lambung Mangkurat University, Indonesia
}

DOI: $\underline{\text { 10.36348/sjhss.2021.v06i02.004 }}$ | Received: 28.01 .2021 | Accepted: $12.02 .2021 \mid$ Published: 13.02 .2021

*Corresponding author: Budi Suryadi

\section{Abstract}

The uneven distribution of population in Indonesia resulted in many problems that must be experienced by the government and society in fulfilling the population administration data. The method used in this research is a qualitative method. Data collection techniques are carried out using participatory observations, interviews and documentation studies. Data analysis is done with descriptive techniques through three flows of activities that are one unity, namely: data reduction, data presentation and conclusion drawing. The results showed that the innovation of Indonesia's movement-conscious administration program includes 16 innovations in communication, resources and bureaucratic structures in population data collection services with inhibitory factors consisting of uneven socialization, low public arrest in understanding the procedures of population requirements and limited aging resources and poor budget in the implementation of population data collection and supporting factors including responsive employees, good communication between employees, support of adequate facilities and infrastructure.

Keywords: Innovation, Indonesian movement program conscious administration, population.

Copyright () 2021 The Author(s): This is an open-access article distributed under the terms of the Creative Commons Attribution 4.0 International License (CC BY-NC 4.0) which permits unrestricted use, distribution, and reproduction in any medium for non-commercial use provided the original author and source are credited.

\section{INTRODUCTION}

Uneven population distribution in Indonesia resulted in a lot of problems that must be experienced by the government and society in fulfilling the population administration data. The current government must be able to capture data on population in an area including areas whose population is vulnerable to population, administration caused by natural disasters and victims of social disasters, such as prison people, elderly people, and disabilities.

This has been confirmed in the Regulation of the Minister of Home Affairs No. 11 of 2010 concerning Guidelines for Data Collection and Issuance of Population Documents for Penduduk Rentan Population Administration. The condition of Indonesian citizens who have vulnerable populations of population, administration becomes an important task for the government in population administration activities.

To reach data collection for vulnerable populations in 2018 the government issued Indonesia's movement-conscious administration program. Indonesia's movement-conscious administration program is a movement to build a government ecosystem that is aware of the importance of population administration. Awareness is indicated by 4 things, namely awareness of urgent population documents, aware of population data updates, the importance of utilization of population data, and awareness of administrative services that make people happy.

Population and civil records are one of the mandatory affairs of local government that must be carried out by the central government to the local government. Population administration services consisting of population registration and civil registration services are sub-sections of public services that must be carried out properly in the community.

In carrying out the administration of population, the important events of residence that include birth, death, stillbirth, marriage, divorce, child recognition, ratification of children and others that must be recorded in the civil registry must be organized 
properly in the form of public service to the community. Birth and death is an important event of population that must be done data collection and become an important part in the administration for the implementation of good population administration.
Banjarbaru City Government of South Kalimantan is a party to Indonesia's movementconscious administration program in order to regulate and increase public awareness about the importance of taking care of population documents. For the electronic management of resident identity cards, birth certificates, death certificates and family cards in Banjarbaru City, you can see the recap data as follows:

Table-1: Population Document Management Data Recap Banjarbaru City 2018-2019

\begin{tabular}{|l|l|l|l|}
\hline No & $\begin{array}{l}\text { Types of } \\
\text { Population } \\
\text { Documents }\end{array}$ & $\begin{array}{l}\text { The Number of People Who } \\
\text { Have Taken Care of } \\
\text { Population Documents }\end{array}$ & $\begin{array}{l}\text { Number of People Who } \\
\text { Have Not Taken Care of } \\
\text { Population Documents }\end{array}$ \\
\hline $\mathbf{1}$ & $\mathbf{2}$ & $\mathbf{3}$ & $\mathbf{4}$ \\
\hline 1 & Identity Card & 64,794 People & 103,521 People \\
\hline 2 & Birth Certificate & 53,766 People & 6.498 People \\
\hline 3 & Death Act & 1,351 People & 1,351 People \\
\hline 4 & Family Card & 71,907 People & 72,514 people \\
\hline
\end{tabular}

Source: Processed Researchers, 2020

Based on data table 1 that the population Banjarbaru city has not fully realized the importance of taking care of population documents. This is due to the lack of public knowledge of the importance of electronic functions of identity cards, namely identity and to support the realization of the accurate population database.

The deed in the field shows lack of awareness and knowledge of the community due to the lack of socialization from the government to the community and inadequate quantity of human resources that provide services so that the service has not been optimized to the community in Banjarbaru.

The local government needs to innovate in order to succeed the Indonesian movement program aware of population, administered in its local communities that have differences in population distribution and construction of regional geographical environments. The need for reformation in public sector management appears to come from the community's pressure demanding the public sector to produce quality products by applying the concept of business management to public services [1].

The innovation model is very diverse, but one of them is in the choice of technology user [2] Innovation needs to be managed and planned, not contingency results. Innovation requires conscious effort to develop and implement ideas [3] Public sectors experience more enormous pressures to strengthen the services and quality management by innovating both in technology and management [4].

\section{RESEARCH METHODS}

The approach that will be used in the innovation, research program of the Indonesian movement, conscious administration is a qualitative approach which is a process of research and understanding based on a methodology that investigates a social phenomenon and human problems. In this approach, researchers create a complex picture, examine words, report detailed from the informant's point of view, and conduct studies on natural situations [5] Qualitative method a research procedure that produces descriptive data in the form of written and oral words from people and observed behaviors [6].

Qualitative research knows no population and no sample. Even if the word sample appears in a qualitative method, then the sample is not representative of the population, but more applied as a case that has its own characteristics, which does not have to be the same as the characteristics of the population it represents [7].

Data collection techniques are carried out based on complete observers, where researchers are not seen in the activities of the research subjects, but still make observations related to research objects using the five senses, especially the eyes and ears [8] Direct observation in the field carefully, interviews are used to obtain primary data through unstructured interview techniques, and studies in the form of document studies related to the innovation of the Indonesian movement program conscious administration.

Data analysis is a process of systematically searching and compiling data obtained from interviews, field records and documentation so that it is easy to understand and its findings can be informed to others. Data analysis using interactive analysis, namely data collection, data reduction, data display and inference and verification [9].

The data process that has been stated is carried out continuously by studying the data, grouping data, finding what is important in accordance with research 
problems and studying and deciding what to report. Through this analysis, it is attempting to reveal what data still needs to be searched, what questions to answer, and what ways to update. The matrices of interactive data analysis are as follows:

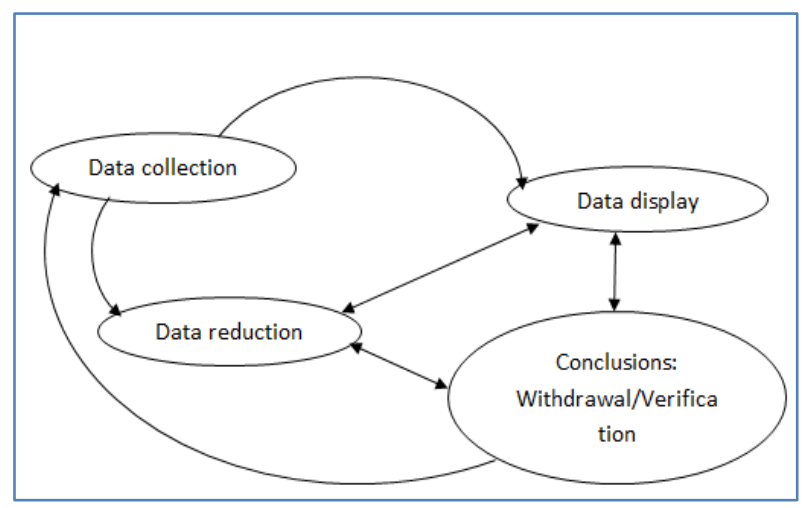

\section{RESULTS AND DISCUSSION}

The development of Banjarbaru City of South Kalimantan Province, which is very rapid over time, from the aspects of population growth, economic growth, social dynamics, culture and politics is very high, as well as the number, qualifications and potential government employees, requires accurate population data for smoothness and success and accuracy in its development programs.

This is expressly stated in the Regulation of the Minister of Home Affairs No. 11 of 2010 concerning Guidelines for Data Collection and Issuance of Documents, Population for Vulnerable Population Administration. The condition of Indonesian citizens who becomes a vulnerable population, administration of this population an important task for the central and local governments in population administration activities.

Where residents must come and report it to the local Civil Registration and Population Office even though the office is quite far from where they live. However, in order to reach the population data collection, such as the condition, then in 2018 the government issued a the Indonesian administration conscious movement program.

The Indonesian movement program is aware that the administration is a movement to build a government ecosystem that is aware of the importance of population administration. Awareness is indicated by 4 things, namely awareness of pentingnya population documents, aware of population data updates, the importance of utilization of population data, and awareness of administrative services that make people happy.

As part of the central government, Banjarbaru City government innovates in the implementation of the Indonesian movement program aware of this population, administration in order to realize the governance of accurate population data. The innovation review of the Indonesian movement program aware of population, administration in Banjarbaru city consists of several aspects [10] as follows, namely:

1. Aspects of communication which include activities:

a. One day service finished is One day service furnished or known as LARI SAY has been established by the Mayor of Banjarbaru as a slogan at the Civil Registration \& the Population Office of Banjarbaru. LARI SAY in addition to meaning as the slogan Of Day Service Finish also has a philosophical meaning. Running contains the meaning of movement / moving continuously (not stopping) to make changes to the specified destination. Whereas SAY means a call or invitation with tenderness, warmth and compassion. The philosophy of LARI SAY also means inviting all relevant components or stakeholders both internally and externally to make changes in a better direction with a warm invitation so that it is consciously and sincerely to support the improvement efforts made by the Civil Registration $\&$ the Population Office of BanjarbaruCity;

b. Mental Tanduk. Digitization of document requirements, as it is known that the use of paper as a requirement for the management of the creation of population, administration documents make the attached files of the community into many, so that in the storage of files also become piled up and difficult to find if the requirements documents are needed again, in addition, if the public will take care of the population, administration documents need to provide again, these requirements, this is considered very ineffective that results in repeated files of the same requirements and the accumulation of files in archival management in a room limited to the general subsection and staffing that is expected to be carried out the maintenance of dynamic records in digital form therefore the application of the requirements of population administration services to the community originally in the form of physical documents sheet paper into in the form of digital documents

c. 2,3,4 Sakali Gawi. The Civil Registration and Population Office of Banjarbaru City has other innovations, namely 2, 3, 4 Sakali Gawi is coming to process or take care of population documents will get 2 population documents at once or 3 documents or even 4 population documents. In other words simplifies the settlement in managing population documents with a single management of 2, 3, 4 documents obtained this innovation to answer the needs of the community for speed and efficiency in managing population documents. So that people do not have to go back and forth to take care of one document and then take care of the next document. However, the implementation of 2, 3, and 4 Sakali Gawi community users still have to 
complete the community in accordance with the applicable rules only direct management so one is not alone;

d. Lapat delicious. Abbreviation of birth can be a child dead and a population, administration service in the form of birth certificate. The implementation of Lapat delicious services in the form of newborn babies at The Regional Hospital Idaman Banjarbaru is entitled to get birth certificates directly. This innovation was supported by the signing of the same agreement between the Civil Registration and Population Office of Banjarbaru City and Idaman Banjarbaru Regional Hospital. Lapat Tasty has the terms of provisions, namely children born in the Regional Hospital Idaman Banjarbaru, citizens have a resident identity card Banjarbaru City, file complete and correct, arrangement documents Lapat delicious by regional hospital officers Idaman, candidate baby Must have prepared the baby's name;

e. Push Beca stands for document freelance brokers are the ministry of population documents in the Department of Population and Civil Registration Banjarbaru City free from registration. It is expected that residents who want to take care of the population documents can directly take it to the Civil Registration and Population Office of Banjarbaru City without going through the intermediary of others. If it is in power, then the person in power must be listed on the family card;

f. Jebol abbreviation to pick up the mobile recording ball is by visiting a predetermined location to do the recording of resident identity cards for people who have not done the recording. People no longer need to date the Civil Registration and Population Office of Banjarbaru City to do the recording. The recorded location is determined directly by the Civil Registration and Population Office of Banjarbaru City;

g. Pelanduk, 6 In 1 is a 6 in 1 population, administration service at the Civil Registry and Population Office of Banjarbaru City means community service that takes care of populating documents namely 6 documents 1 management namely non-Muslim marriage. 6 in 1 saddle innovations include services in the form of marriage certificates, resident identity card change status for husband brides, resident status change cards for brides, new family cards for brides and grooms, family solving cards for husband's family, family solving cards for the wife's family;

h. Pelanduk, 5 In 1 is a population, administration service 5 In 1 in the Department of Population and Civil Registration Banjarbaru means the Population Administration Service in one service will get 5 population documents at once, namely in the management of divorce deed for non-Muslim Innovation Pelanduk, 5 In 1 includes services in the form of a divorce certificate, identity card status change for ex-husband, identity card status change for ex-wife, family card solving for ex-husband, family card solving for ex-wife;

i. The Posyandu program stands for Posyandu Population Administration Service, which is for people, especially pregnant women who give birth through posyandu who will soon get a birth certificate after the delivery process. Where this innovation is a form of service of the Civil Registration and Population Office of Banjarbaru City in collaboration with Posyandu. The Posyandu plan has a provision for a baby born to a pregnant woman recorded in the local Posyandu, by creating a birth certificate service for babies born by human rights mothers recorded at the local Posyandu. Data collection recorded the results of services from Posyandu cadres and midwives to make reports to the village and city government;

j. Lauk Sepat, abbreviation of affair services certificate, death immediately at the Department of Population and Civil Registration Banjarbaru city is the service of making death certificates quickly and efficiently for the community maximum on the same day at the time of management. Lauk Sepat has a provision in the form of a certificate of death from the hospital, health center or post mortem doctor, original and photocopy of family cards and identity cards of deceased residents and applicants, original and photocopy of marriage certificate / marriage certificate in the case of the deceased already married, original and photocopy of the quotation of the deceased birth certificate;

k. Star four, abbreviation My midwife came to get my deed is a population, administration service to the community, especially pregnant women who give birth through individual midwives or clinic midwives who will soon get a birth certificate after the delivery process. Four stars began to be tested after being approved and determined by the Mayor of Banjarbaru in May 2019, where this innovation is a form of Department of Population and Civil Registration services in collaboration with the Health Agency of individual midwives or clinic midwives with the aim of obtaining patient health information to be used in determining the relevant population policy so as to create optimal services in all clinics in the community

1. Katapelku datanglah is an innovation of my resident card coming to schools is a population, administration service for school students by visiting schools. Katapelku come has been implemented in May 2019 after the signing of a decree by mayor Banjarbaru, where this innovation was carried out by the Civil Registration and Population Office of Banjarbaru City by working with the Education Office of Banjarbaru City to conduct recordings to schools aimed at students who have turned 17 years old;

m. Lapat, a fast service for sick and disabled parents, is the service of all forms of population, administration services that prioritize the elderly, people who are 
sick and with disabilities secret quickly and appropriately. Lapat for sick and disabled parents was implemented in May 2019. The obstacles faced in implementing Lapat sick and disabled parents are not optimal support fund activities and the quality and quantity of human resources is still limited;

n. Card identity goes to school is a card identity a son comes to school means carrying out the service of making children's identity cards by visiting schools where for the Banjarbaru City itself prioritizes the creation of child identity cards for children ahead of elementary school to junior high school and high school. Since the issuance of the child identity card policy through the Ministry of Home Affairs Regulation No. 2 of 2016, program the creation and ownership of child identity cards has been valid nationally and in Banjarbaru City is effective in 2019;

o. Orderly village adminstrasi is carrying out services orderly village administration in order to improve the quality of population, administration services are innovative, fast, accurate and free with the aim of making citizens or the community happy in terms of population administration services. Card, the first administrative order that will soon be established by the government in 2019 in Banjarbaru City, is the village of North Banjarbaru with 10 neighborhoods and 2 pillars of residents;

p. Peri Tugu stands for service on Saturdays and Sundays at the Civil Registration and Population Office of Banjarbaru City is a service of administrations there holidays that are Saturday and Sunday to maximize service in an effort to accelerate the recording of population data to welcome the election of regional heads in 2020. Peri tugu is a new program that was implemented in April 2019.

Based on the 16 innovations of population, administration services made, the Department of Population and Civil Registration expects in the future that the people of Kota Banjarbaru will become more aware of the importance of taking care of all population documents whether it has a population document or updating the population data that has been owned. There is no reason not to take care of the population documents because through innovations it made it easier for people to take care of population documents in order to succeed and optimize the program movement Indonesia aware of the administration made. Then an indicator contained in the aspect of communication, namely:

First, transmission is the main factor in the communication of policy implemented The transmission dimension that has been implemented in the Indonesian movement program is administratively conscious, namely socialization both directly and indirectly.
The obstacles in this transmission are the limited community participants who are socialized designated from community leaders from each citizens association neighbors nor citizens association residents so that the next one can transfer socialization information to the community in the environment, in addition to socialization is also in the installation of billboard in a strategic place also in the value of appropriate and through social media, but there are obstacles and in receiving understanding when the management of population files come to Department of Population and Civil Registration, the community is always incomplete in carrying out population documents;

Second, the clarity of socialization material that is delivered is clear because it has been regulated by the provisions of legislation. The obstacle in this case is the figure that brings socialization. The figure of the resource person who conveys the material is sometimes unclear in terms of language, articulation, body gesture and mastery when delivering socialization materials, limited socialization time, space conditions and layout during socialization, so that the information submitted is not absorbed maximally by the socialization participants;

Third, Consistency in the program of the Indonesian movement, conscious administration, this must be in line with the main objectives of the program, namely document ownership awareness program, data update aware program, aware program of utilization of population data as the only data used for all interests, program consciously serve the administration of population towards a Happy society. Continuous and consistent program implementation facilitates the achievement of expected results in accordance with the expected goals.

2. Aspects of human resources include activities:

a. Human resources. Human resources will not succeed without the support of human resources of sufficient quality and quantity. The quality of human resources related to skills, dedication, professionalism and competence in their field, while quantity relates to the number of human resources whether it is enough to cover the entire target group. The Civil Registration and Population Office of Banjarbaru City against the response of employees in recording the population of both civil servants and civil apparatus of the state as well as honorary personnel when dealing with the community is good value and satisfactory. Officers in registering the population at each counter are able to resolve complaints and public unrest when taking care and updating the population documents without having to ask for help from the supervisor who in this case is the head of the section, the head of the field, secretary and head of service unless it are urgent. Officers or employees who serve is 
good and running maximum because it applies to 3 $\mathrm{S}$ (greetings, greetings, smiles) according to information provided by the ministry that encourages the Indonesian movement to be aware of the administration

b. Facilities. Infrastructure in the program movement process Indonesia is aware of this administration is adequate in terms of facilities, computer, printer, retrieval room, lactation room, public toilets, children's play area, disabled toilets and the existence of a suggestion box for the implementation of orderly population documents;

c. The appointment of bureaucrats. Attitudes and disciplines in the discipline become one of the primary keys in the appointment of bureaucracy with attitude, ability and personal will. Misplacement and personal appointment, regardless of discipline, attitude, ability or ability, have the potential to be large in the failure of program policy implementation. Therefore, before the bureaucratic dilution must be done the first study with the best by paying attention to references from people around. Including the ministers who are in the Civil Registration and Population Office ofBanjarbaru City based on the consideration of the mayor, governor and Minister of Home Affairs based on Permendagri No. 76 of 2015 so that for the ability to serve no doubt;

d. The value of incentives DI Department of Population and Civil Registration Banjarbaru City in accordance with the regulation No. 80 of 2017 for the addition of the official allowance of the Head of the Civil Registration and Population Office (echelon II/b) of Rp.8.500.000, head of the field (echelon III/b) of Rp.5.000.000, - head of section (echelon IV.b) of 3.000.000, and staff amounting to Rp.1.450.000, - this is an incentive given to employees on duty in the Civil Registration and Population Office of Banjarbaru City, in addition there is also honor overtime for each officer of Rp.150.000, -/ day and this figure is only for staff or executives different from the officials, with cost set to carry out the activities provided.

3. Aspects of bureaucratic structure include activities:

a. Standard operating procedures. Standard operating procedures serve to form a system of work and flow that is organized, systematic and accountable. Operating procedure's standards describe how the purpose of the work is carried out in accordance with applicable policies and regulations. Standard operating procedures also explain how the process of implementing activities as for the guidelines is local regulations No. 04 of 2017 concerning the implementation of Population Administration article 6 paragraph 1 states "Local Government has obligations and responsibilities to carry out the affairs of Population Administration" on the basis of which the obligations are delegated to the Civil
Registration and Population Office of banjarbaru city as the service that handles it;

b. Fragmentation aims to spread responsibility as activities, activities, or programs in several work units in accordance with their respectively, with fields. Fragmentation of bureaucratic structure, the program will be more effective because it is implemented by competent and capable organizations. Part of duties and responsibilities respectively, with the strengthened existence of mayoral rules No. 46 of 2016 on the position, organizational structure, main duties and function and work procedures of the Civil Registration and Population Office of Banjarbaru city based on their respective duties both handling, recording, logging, printing, supervision and execution in the expenditure of document to be published legally.

As for the inhibitory factor in innovation program Movement Indonesia conscious administration is still many people of Banjarbaru City who do not understand the process of applying for the use of population documents such as resident identification cards, family cards, birth certificate, death certificate and others.

This is because don't understand the benefits of the population document and the reluctance of the community to take care of the population documents, although there have been 16 innovations from the Department of Population and Civil Registration banjarbaru city to support the program movement Indonesia aware of the administration is still the public cannot take a little time to take care of the population documents, which is evident when it comes to the office of the Civil Registration and Population Office of Banjarbaru City to the service counter, the queue has been preceded by others have not even completed the requirements requested even though the requirements have been informed either through social media or down to the field from the officers.

Supporting factors in the innovation of the Indonesian movement program aware of the administration is employees who respond to the impact is very feels in the community of Banjarbaru city itself because there is no impression of complicating even convoluted in managing and updating population data be it family cards, resident identification cards, birth certificates, death certificates and others.

Other supporting factors innovate this program in line with government policy in the management of documents and updating the population data such as electronic signature card, family card, birth certificate, death certificate for the people of Banjarbaru city because it already has a built-in policy or already has a task and functions. The Civil Registration and Population Office of Banjarbaru City innovated 16 programs for population in order to make it easier for 
the people of Banjarbaru City take care of and update the population documents.

\section{CONCLUSION}

The conclusion of this study is that the Inovasi Movement Indonesia Conscious Administration Program includes 16 innovations in population data collection services in communication, resources, disposition and bureaucratic structure. The inhibition factor consists of uneven socialization, low responsiveness society in understanding the procedures of population requirements and limitations of human resources and budgets that are lacking in the implementation of population data collection. Supporting factors include responsive employees, good communication between employees, support of adequate facilities and infrastructure.

\section{REFERENCES}

1. Akhmad, B. A. (2020). Communicating the dissatisfaction in workplace among public sector employees: loyalty and neglect as an alternative model of responses.

2. Rajiani, I., \& Ismail, N. (2019). Management innovation in balancing technology innovation to harness universities performance in the era of community 4.0. Polish Journal of Management Studies, 19.

3. Den Hertog, J.P. (1985). Mechanical Vibration. New York: Dower Publications, Inc

4. West, M.A., \& Farr, J.L. (1990). Innovation and Creativity at Work: Psychological and Organizational Strategies. University of California: Wiley.

5. Moleong, L. (2013). Qualitative Research Method: Revised Edition Bandung: PT Remaja Rosdakarya.

6. Bogdan, R., \& Taylor, S.J. (1975). Introduction to Qualitative Research Methods: A Phenomenological Approach to The Social Sciences. New York: John Wiley \& Sons.

7. Soehartono, I. (2011). Social Research Method. Bandung: Rosdakarya Teens.

8. Creswell, John, W. (2009). Research Design: Qualitative, Quantitative, and Mixed Methods Approaches. Third Edition. London: Sage Publication Inc.

9. Miles, M. B., \& Huberman. (1984). A Qualitative Data Analysis: A Sourcebook of New Method. London: Sage Publications, Inc

10. Edward, III, G.C. (1980). Implementing Public Policy. Washington: Congressional Quarterly Inc. 